\title{
BEZPODSTAWNE WZBOGACENIE PRACOWNIKA
}

Niezaprzeczalną cechą stosunku pracy, czy to wynikającego z umowy, czy też z innych aktów ${ }^{1}$, jest jego zobowiązaniowy charakter ${ }^{2}$. W związku z tym, choć stosunek pracy regulowany jest przede wszystkim przepisami Kodeksu pracy $^{3}$ i innymi aktami tej gałęzi prawa, do kwestii nieuregulowanych odpowiednie zastosowanie winny znaleźć przepisy Kodeksu cywilnego ${ }^{4}$, z racji odesłania z art. 300 k.p, o ile nie będą one stały w sprzeczności z zasadami prawa pracy $^{5}$. Tym samym stosowanie przepisów k.c. do k.p. nie jest bezwarunkowe. Poszczególne przepisy k.c. nie znajdą zastosowania, jeśli doszłoby przez to do naruszenia standardów ochrony pracowniczej przewidzianej w k.p. W kontekście odpowiedzialności pracowniczej podnosi się przy tym wagę unormowań zawartych w dziale piątym k.p. i jego autonomiczność względem uregulowań ogólnych, podyktowanych potrzebą ochrony słabszej strony stosunku pracy, co przejawiać się ma np. w obniżeniu należnego od pracownika odszkodowania do wysokości trzymiesięcznego wynagrodzenia, stosownie do art. 119 k.p. (podczas gdy k.c. przewiduje zasadę pełnego odszkodowania, zgodnie z art. 361 $\S 1$ k.c.) lub też ograniczeniu zakresu odszkodowania wyłącznie do rzeczywistej szkody (gdy w stosunkach cywilnoprawnych obejmuje ona także utracone korzyści, zgodnie z art. $361 \S 2$ k.c.).

${ }^{1}$ Dotyczy to z cała pewnością stosunku pracy z wyboru i powołania (por. M. Barzycka-Banaszczyk, Kodeks pracy. Komentarz, Warszawa 2000, Legalis [dostęp: 27.11.2017]. Podobne uwagi doktryna czyni także odnośnie do stosunku pracy z mianowania - tak M. Święcicki, Przedmiot prawa pracy, w: Z. Salwa, W. Szubert, M. Święcicki (red.), Podstawowe problemy prawa pracy, Warszawa 1957, s. 21-22; W. Jaśkiewicz, Stosunek stużbowy a stosunek pracy, „Ruch Prawniczy, Ekonomiczny i Socjologiczny" 22, 1960, z. 2, s. 32. Niemniej w nauce prawa administracyjnego stosunek powstały z mianowania ocenia się na podstawie tylko i wyłącznie przepisów prawa administracyjnego (T. Zieliński, Stosunek prawa pracy do prawa administracyjnego, Warszawa 1977, s. 145-147), co ma wynikać z faktu, że akt mianowania stanowi - wedle orzecznictwa i niektórych poglądów doktryny - decyzję administracyjna (por. wyrok NSA z 24 września 1991 r., II SA 746/91, „Orzecznictwo Sądów Polskich” 1992, nr 3, poz. 64).

${ }^{2}$ H. Szewczyk, Ochrona dóbr osobistych w zatrudnieniu, Warszawa 2007, s. 178; E. Maniewska, Obowiazki informacyjne pracodawcy wobec pracownika $w$ umownym stosunku pracy, Warszawa 2013, s. 24-25; D. Książek, Miejsce pracy jako istotny element umowy o prace, Warszawa 2013, s. 55.

${ }^{3}$ Ustawa z 26 czerwca 1974 r. - Kodeks pracy, Dz. U. 2016, poz. 1666.

${ }^{4}$ Ustawa z 23 kwietnia 1964 r. - Kodeks cywilny, Dz. U. 2017, poz. 459.

${ }^{5}$ K. Roszewska, Skutki sprzeczności przepisów Kodeksu cywilnego z zasadami prawa pracy, „Praca i Zabezpieczenie Społeczne” 2005, nr 2, s. 22; K. Wielichowska-Opalska, Stosowanie przepisów KC o odpowiedzialności za szkodę w razie niezgodnego z prawem rozwiazania stosunku pracy przez pracodawcę, „Monitor Prawa Pracy” 2010, nr 7, s. 350-355.

${ }^{6}$ S. Koczur, Aksjologia odpowiedzialności materialnej pracownika, Warszawa 2017, Legalis [dostęp: 2.01.2018]. 
Dla praktyki i teorii prawa oznacza to tyle, że stosowanie znacznej części przepisów Kodeksu cywilnego regulujących odpowiedzialność budzi istotne wątpliwości na tle dopuszczalności ich stosowania w stosunku pracy. Tytułem przykładu można wskazać, że nie ma większych wątpliwości co do stosowania ochrony dóbr osobistych pracownika w związku z prowadzonym przeciwko pracownikowi postępowaniem dyscyplinarnym, na podstawie art. 23 i 24 k.c. w zw. z art. 300 k.p. ${ }^{7}$, czy co do stosowania przepisów o wadach oświadczenia woli wprost $t^{8}$. Z drugiej strony często odmawiano skuteczności przepisom prawa cywilnego w kontekście odpowiedzialności pracowniczej, w tym przepisów o karze umownej ${ }^{9}$ czy też wekslom wydanym na zabezpieczenie roszczeń pracodawcy o naprawienie szkody wyrządzonej przez pracownika ${ }^{10}$.

W dotychczasowej literaturze oraz judykaturze poświęcono stosunkowo mało miejsca kwestii styku odpowiedzialności pracowniczej ${ }^{11}$ oraz odpowiedzialności z tytułu bezpodstawnego wzbogacenia (kondykcji), uregulowanego w przepisach z art. 405-414 k.c. Sąd Najwyższy w wyroku z 27 maja 1999 r. dopuścił zbieg przepisów o materialnej odpowiedzialności pracowników i bezpodstawnym wzbogaceniu, przy jednoczesnym zastrzeżeniu, że nie może to doprowadzić do obejścia reguł odpowiedzialności pracowniczej ${ }^{12}$. Równolegle w krytycznej glosie do powołanego orzeczenia Artura Nowak opowiedział się przeciwko stosowaniu przepisów art. $405-414$ k.c. do stosunku pracy - ze względu na kompletność oraz autonomiczność unormowania odpowiedzialności pracowniczej zawartych w k.p. ${ }^{13}$

Z kolei orzecznictwo SN nie przedstawia jednolitego podejścia do omawianego problemu. Wyrażono wprawdzie tezę o dopuszczalności zbiegu roszczeń ze stosunku pracy z kondykcja ${ }^{14}$, jednakże $\mathrm{w}$ wielu kwestiach wskazuje się odmienności wynikające $\mathrm{z}$ regulacji Kodeksu pracy, wywierających wpływ na zakres odpowiedzialności bezpodstawnie wzbogaconego pracownika. Tytułem przykładu można wspomnieć orzeczenie z 8 czerwca 2010 r., w którym SN uznał, że nie można żądać od pracownika zwrotu nienależnie wypłaconej pensji, jako że jest to sprawa stricte ze stosunku pracy, co nie pozwala na zbieg

7 Postanowienie SN z 16 marca 2000 r., I PKN 673/99, „Orzecznictwo Sądu Najwyższego. Izba Administracyjna, Pracy i Ubezpieczeń Społecznych” 2001, nr 15, poz. 491, 2001, nr 2, s. 61.

8 Tak np. D. Przewłocka, Odpowiednie stosowanie przepisów kodeksu cywilnego o wadach oświadczeń woli do stron stosunku pracy, „Praca i Zabezpieczenie Społeczne” 2017, nr 4, s. 33; odmiennie SN w wyroku z 11 czerwca 2003 r., I PK 206/02, „Orzecznictwo Sądu Najwyższego Izba Pracy” 2004, nr 16, poz. 276.

9 Wyrok SN z 1 października 2003 r., I PK 528/02, „Orzecznictwo Sądu Najwyższego Izba Pracy” 2004, nr 19, poz. 336.

10 Por. wyrok SN z 26 stycznia 2011 r., II PK 159/10, „Orzecznictwo Sądu Najwyższego. Izba Administracyjna, Pracy i Ubezpieczeń Społecznych” 2012, nr 7-8, poz. 87.

11 Odmiennie kształtuje się to w sytuacji odpowiedzialności na tle przepisów o ubezpieczeniach społecznych, por. uchwałę SN z 5 grudnia 2013 r., III PZP 6/13, „Orzecznictwo Sądu Najwyższego. Izba Administracyjna, Pracy i Ubezpieczeń Społecznych” 2014, nr 11, poz. 154, s. 562.

12 Wyrok SN z 27 maja 1999 r., I PKN 78/99, „Orzecznictwo Sądów Polskich” 2001, nr 11, poz. 167 , s. 568 .

13 A. Nowak, Glosa do wyroku Sadu Najwyższego z dnia 27 maja 1999 r., „Orzecznictwo Sądów Polskich" 2001, nr 11, poz. 167, s. 571.

14 Wyrok SN z 13 czerwca 2007 r., II PK 356/06, „Orzecznictwo Sądu Najwyższego. Izba Administracyjna, Pracy i Ubezpieczeń Społecznych” 2008, nr 15-16, poz. 217, s. 634. 
z kondykcja ${ }^{15}$. W innym natomiast orzeczeniu (zapadłym na tle sprawy z powództwa o zwrot nadpłaconego wskutek omyłki systemu elektronicznego wynagrodzenia) SN orzekł, że przepisy o bezpodstawnym wzbogaceniu nie moga służyć do obchodzenia ograniczeń w zakresie pracowniczej odpowiedzialności materialnej wtedy, gdy bezpodstawne wzbogacenie się pracownika ma jednocześnie cechy zawinionego wyrządzenia szkody pracodawcy ${ }^{16}$.

Już pobieżny przegląd orzecznictwa sądów pracy i piśmiennictwa odnośnie do odpowiedzialności pracowniczej na tle przepisów o bezpodstawnym wzbogaceniu pozwala na stwierdzenie, że brak zgodności w judykaturze i doktrynie co do samej dopuszczalności oraz kształtu odpowiedzialności pracownika na tle przepisów o kondykcji. Moim zdaniem wynika to z błędnego rozpoznania istoty samej instytucji bezpodstawnego wzbogacenia oraz nieuzasadnionej modyfikacji tej odpowiedzialności wskutek niewłaściwego stosowanie art. $300 \mathrm{k} . \mathrm{p}$. Jednakże przed wyjaśnieniem tej tezy należy przybliżyć samo pojęcie bezpodstawnego wzbogacenia jako zjawiska prawnego i przedmiotu rozważań nauki prawa ${ }^{17}$. Okazuje się bowiem, że wśród cywilistów nie ma zgodności co do wielu istotnych zagadnień związanych z bezpodstawnym wzbogaceniem. Dla realizacji celu niniejszego artykułu i przybliżenia zjawiska bezpodstawnego wzbogacenia w prawie pracy niezbędne jest w pierwszej kolejności przedstawienie samej instytucji bezpodstawnego wzbogacenia.

Kondykcja stanowi przedmiot żywego zainteresowania przedstawicieli doktryny, brak jednak zgodności co do samej istoty omawianego zjawiska czy też zakresu jego zastosowania. Panuje jednak zgoda co do faktu, że w stosunku do reżimów odpowiedzialności kontraktowej czy też deliktowej jest to pojęcie niezwykle nieostre. Wedle Ewa Łętowskiej stanowi ono pewne „lepiszcze"18 między lukami w systemie prawnym, dalej zaś idzie Alfred Ohanowicz, wedle którego: „Instytucja niesłusznego wzbogacenia należy do najbardziej niejasnych i zawiłych zagadnień w dziedzinie prawa cywilnego"19. Te oceny wynikają z konstrukcji rzeczonej instytucji, ujętej w art. 405-410 k.c.

W Kodeksie cywilnym z 23 kwietnia 1964 r. bezpodstawne wzbogacenie uregulowano unitarnie, razem z pokrewną instytucją nienależnego świadczenia $^{20}$. Stanowi ono - obok czynności prawnych i deliktów ${ }^{21}$ - źródło zobowiąza-

15 Wyrok SN z 8 czerwca 2010 r., I PK 31/10, „Monitor Prawa Pracy” 2010, nr 9, s. 450.

16 Wyrok SN z 27 maja 1999 r., I PKN 78/99, „Orzecznictwo Sądu Najwyższego. Izba Administracyjna, Pracy i Ubezpieczeń Społecznych” 2000, nr 18, poz. 682. O ograniczeniu odpowiedzialności pracowniczej będzie jeszcze mowa.

17 Omówienie wszelkich zagadnień związanych z kondykcją wykraczają poza ramy niniejszego opracowania, dlatego zostaną przybliżone jedynie najistotniejsze zagadnienia.

18 E. Łętowska, Bezpodstawne wzbogacenie, Warszawa 2000, s. 3.

19 A. Ohanowicz, Niestuszne wzbogacenie, Warszawa 1956, s. 7.

${ }^{20}$ Idem, Bezpodstawne wzbogacenie, w: Z. Radwański (red.), System prawa cywilnego, t. 3, cz. 1: Prawo zobowiazań - część ogólna, Wrocław 1981, s. 488-489. Nienależne świadczenie stanowi postać bezpodstawnego wzbogacenia, w przeciwieństwie do pozostałych zdarzeń prawnych klasyfikowanych jako kondykcja nie tyle, ile nie posiada w ogóle podstawy prawnej, lecz podstawa prawna odpadła lub z innych względów jest wadliwa, stosownie do art. $410 \S 1$ i 2 k.c. (wyrok SN z 11 czerwca 2003 r., V CKN 337/01, Legalis [dostęp: 27.11.2017]).

21 A. Rzetecka-Gil, w: eadem (red.), Kodeks cywilny. Komentarz. Zobowiazania-część ogólna, Lex/el. 2015, 8853 [dostęp: 31.10.2017]. 
nia, celem roszczenia wywodzonym z omawianej instytucji jest przywrócenie równowagi naruszonej przez bezpodstawne przejście określonej wartości między majątkami zgodnie z zasadą ekwiwalentności ${ }^{22}$ po wypełnieniu określonych prawem przesłanek.

Przesłanki, o których mowa powyżej, określa art. 405 k.c.: „kto bez podstawy prawnej uzyskał korzyść majątkowa kosztem innej osoby, obowiazany jest do wydania korzyści w naturze, a gdyby to nie było możliwe, do zwrotu jej wartości”. Odpowiedzialność z tytułu kondykcji, w myśl powołanego przepisu, powstaje między wzbogaconym a zubożonym wówczas, gdy po dłużnej stronie (tj. wzbogaconego) dojdzie do uzyskania korzyści majątkowej (wzbogacenia) kosztem zubożenia strony wierzycielskiej ${ }^{23}$ przy jednoczesnym braku podstawy prawnej ${ }^{24}$ oraz - choć tylko niektórzy przedstawiciele nauki wyróżniają ten element ${ }^{25}$ - istnieniu związku przyczynowo-skutkowego.

Samo wzbogacenie, warunkujące odpowiedzialność z tytułu kondykcji, definiowane jest szeroko, jako zwiększenie aktywów, zmniejszenie pasywów ${ }^{26}$, w tym - przykładowo - umocnienie prawa, zwolnienie z długu, zaoszczędzenie wydatków na nabycie pewnych dóbr, świadczenie usługi przy jednoczesnym braku prawnej podstawy przysporzenia ${ }^{27}$. W każdym razie nie ma w doktrynie wątpliwości, że zgodnie z litera art. 405 k.c. wzbogacenie ma wyłącznie wartość pieniężną bądź dającą się wyrazić w pieniądzu. Kwestie przysporzeń o charakterze moralnym czy też duchowym są zatem wyłączone ${ }^{28}$.

Wzbogaceniu jednej ze stron stosunku zobowiązaniowego z bezpodstawnego wzbogacenia najczęściej odpowiada ${ }^{29}$ zubożenie drugiej strony. Piszę „najczęściej”, jako że nie ma pewności w doktrynie, czy każdorazowo musi dojść do zubożenia potencjalnego wierzyciela. Podaje się tym zakresie przykład, że nie dochodzi do stanu zubożenia w sytuacji, gdy ktoś bezprawnie korzysta

${ }^{22}$ Wyrok SN z 13 maja 1988 r., III CRN 83/88, „Orzecznictwo Sądu Najwyższego Izby Cywilnej, Pracy i Ubezpieczeń Społecznych” 1989, nr 5, poz. 84.

${ }^{23}$ Odmiennie: P. Księżak, Bezpodstawne wzbogacenie. Art. 405-414 KC. Komentarz, Warszawa 2007, s. 58 i n. Powołany autor stoi na stanowisku, że samo zubożenie nie jest obligatoryjną przesłanką odpowiedzialności z kondykcji. Jego zdaniem do odpowiedzialności dochodzi wówczas, gdy wzbogacenie nastapiło samym kosztem innej osoby, bez podstawy prawnej. Dla uargumentowania ww. stanowiska P. Księżak podkreśla różnice między obecnym brzmieniem k.c. a dawnym art. 123 Kodeksu zobowiązań - w którym ustawodawca wyraźnie uzależnił roszczenie o zwrot od zubożenia wierzyciela od wystapienia stanu zubożenia.

${ }^{24}$ Wyrok SN z 6 listopada 2015 r., II CSK 870/14, Legalis [dostęp: 28.11.2017].

25 Również i w orzecznictwie często napotkać można pogląd, że związek przyczynowo-skutkowy nie jest przesłanką bezpodstawnego wzbogacenia. Podnosi się, że w ramach kondykcji dochodzi nie tyle co do związku przyczynowo skutkowego z art. 361 k.c., lecz do koincydencji, istnienia wspólnej przyczyny zubożenia i wzbogacenia (wyrok SA w Łodzi z 25 lutego 2014 r., I ACa 1121/13, Legalis [dostęp: 28.11.2017]. Odmiennie: wyrok SN z 16 grudnia 2014 r., I BP 3/14, Legalis [dostęp: 28.11.2017]).

${ }^{26}$ K. Pietrzykowski, w: idem (red.), Kodeks cywilny, t. 1: Komentarz do art. 1-449(10), Warszawa 2013, s. 1138 i 1139.

27 P. Mostowik, w: A. Olejniczak (red.), System prawa prywatnego, t. 6, Warszawa 2014, s. 255 .

28 Ibidem.

${ }^{29}$ Choć nie zawsze w pełnym rozmiarze - por. wyr. SN z 24 października 1974 r., II CR 542/74, „Orzecznictwo Sądów Polskich” 1976, nr 6, poz. 115. 
z cudzej rzeczy. W tym zakresie część autorów przyjmuje, że dochodzi do istnienia wzbogacenia bez zubożenia ${ }^{30}$, inni wychodzą z założenia, że o istnieniu zubożenia decyduje sam fakt, iż uprawniony mógł potencjalnie odnieść przysporzenie $^{31}$. Faktem jest, że nie w każdej konfiguracji faktycznej musi dojść do przeniesienia (w sensie fizycznym) konkretnego dobra czy prawa pomiędzy majątkami.

W tym miejscu warto wspomnieć, iż E. Łętowska ${ }^{32}$ podkreśla, że nie można mówić o wystapieniu bezpodstawnego wzbogacenia w sytuacji braku transferu pomiędzy stroną dłużną a wierzycielską. Podaje w tym zgodę nabywcy samochodu na pokrycie w ramach ceny sprzedaży kwoty niespłaconego kredytu, zaciagniętego przez poprzedniego właściciela na kupno tego pojazdu. Pomniejsza to wprawdzie koszt samej transakcji (określona kwota odciąża koszt nabycia, zostaje zaś przekazana na spłatę kredytu), nie ma jednak transferu składnika majątkowego między rzekomym dłużnikiem a rzekomym wierzycielem. W tej sytuacji nie powstaje roszczenie z bezpodstawnego wzbogacenia ${ }^{33}$. Stanowisko to nie jest bezdyskusyjne. Jak już podkreślono wcześniej, Paweł Księżak uważa, że przez pojęcie „kosztem innej osoby” należy rozumieć także takie zaszłości, które nie wyrządziły uszczerbku majątkowego w sferze potencjalnego. Nie ma zatem zgodności w doktrynie co do konieczności przesunięć majątkowych między wierzycielem a dłużnikiem kondykcyjnym ${ }^{34}$.

Następną i najistotniejszą przesłanką roszczenia kondykcyjnego jest brak prawnej podstawy wzbogacenia ${ }^{35}$, która występuje wówczas, gdy dane przysporzenie nie wynika z przepisów prawa pozytywnego, czynności prawnej, orzeczenia sądu lub z aktu administracyjnego ${ }^{36}$. Więcej uwag w tym przedmiocie zostanie poczynionych w dalszej części opracowania.

Innym istotnym zagadnieniem, często poruszanym w piśmiennictwie, jest kwestia subsydiarności ${ }^{37}$ roszczeń z tytułu kondykcji w stosunku do innych.

${ }^{30}$ P. Księżak, op. cit., s. 50-51 i 69-70.

31 E. Łętowska, op. cit., s. 65 i n.

32 Ibidem, s. 75.

${ }^{33}$ Przykład zaczerpnięty przez E. Łętowską z wyroku SN z 4 kwietnia 2000 r., V CKN 6/00, „Orzecznictwo Sądu Najwyższego Izby Cywilnej” 2000, nr 10, poz. 185, s. 54.

${ }_{34}$ Zdaniem autora niniejszego artykułu pogląd co do konieczności przyjęcia transferu za przesłankę roszczenia jest zgodny z brzmieniem powołanego wcześniej art. 405 k.c., zgodnie z którym wzbogacenie ma nastapić „kosztem innej osoby”, co jednoznacznie wskazuje na przejście określonego prawa z jednego majątku do drugiego. Niemniej jest to problematyczna sytuacja wobec zasygnalizowanych już wcześniej wątpliwości, czy za każdym razem wzbogaceniu musi odpowiadać zubożenie. Jeśli taka sytuacja nastapi, to nie będzie można w ogóle mówić o transferze.

${ }^{35}$ Dla zupełności wywodu warto wspomnieć, że dawniej postrzegano tę przesłankę jako sprzeczność wzbogacenia z prawem naturalnym. O powstaniu roszczenia z kondykcji decydowała, nawet wobec zgodności z prawem przesunięcia majątkowego, ocena aksjologiczna. Przykładowo: orzeczenie SN z 15 września 1945 r., C I 116/45, „Państwo i Prawo” 1946, z. 2, s. 120. Za takim kształtem i rozumieniem omawianej instytucji przemawiała także jego przedwojenna nazwa „niesłuszne” wzbogacenie.

${ }^{36}$ K. Pietrzykowski, op. cit., s. 1139.

37 Autor artykułu zdaje sobie sprawę z wieloznaczności pojęcia subsydiarności, które może odnosić się do kwestii powstania samego roszczenia (wtedy sam byt roszczenia uzależniony jest od niepowstania innych roszczeń), a także do kwestii skorzystania z samego roszczenia (wtedy subsydiarność rozumie się jako nieskuteczne wykorzystanie roszczeń z innych tytułów prawnych). To 
Bezpodstawne wzbogacenie obejmuje bowiem szeroki katalog przypadków, niemożliwy do określenia na poziomie naukowej abstrakcji. Tym samym roszczenie z bezpodstawnego wzbogacenia może konkurować z innymi roszczeniami, $\mathrm{w}$ tym z prawa rzeczowego ${ }^{38}$, czy z roszczeniami odszkodowawczymi ${ }^{39}$. Powstaje zatem wątpliwość, czy kondykcja może bez ograniczeń konkurować z innymi roszczeniami, czy też można korzystać z mechanizmów z art. 405-415 k.c. wyłącznie wtedy, gdy niemożliwe lub znacznie utrudnione jest użycie innych roszczeń. Za subsydiarnością kondykcji opowiedziało się np. prawo włoskie ${ }^{40}$. Natomiast prawo polskie ograniczyło się do niejasnej formuły z art. 414 k.c., zgodnie z którym przepisy rozdziału niniejszego (tj. regulujące przedmiotowe zagadnienie) nie uchybiaja przepisom o obowiązu naprawienia szkody. Przepis ten można bowiem interpretować zarówno jako generalne potwierdzenie zbiegu roszczeń, jak i jako wyjątek od subsydiarności ${ }^{41}$. Podobny przepis można odnaleźć także w art. 287 ustawy prawo własności przemysłowej ${ }^{42}$.

Sprawy nie wyjaśnia również orzecznictwo ${ }^{43}-\mathrm{w}$ tym SN - które skłania się raczej do przyjęcia subsydiarności roszczenia kondykcyjnego $0^{44}$, choć niekiedy SN opowiada się za samodzielnością roszczeń ${ }^{45}$. Z kolei w piśmiennictwie dominuje pogląd na rzecz konkurencyjności ${ }^{46}$. Oba stanowiska znajduja jednak racjonalne podstawy.

Stanowisko na rzecz subsydiarności bezpodstawnego wzbogacenia poparte jest kilkoma argumentami. Podkreśla się, że formuła wskazanego wcześniej art. 414 k.c. jest na tyle szeroka, że nie można wywodzić z niej tezy o dopuszczalności całkowitego zbiegu roszczenia kondykcyjnego z innymi. Wnioskując a contrario z art. 414 k.c., wskazuje się, że gdyby bezpodstawne wzbogacenie miało charakter ściśle autonomiczny, wówczas zbędna byłaby regulacja art. 414 k.c., dopuszczająca zbieg tylko z roszczeniami odszkodowawczymi ${ }^{47}$.

drugie stanowisko jednak, jak wskazuje P. Mostowik, należy odrzucić (por. idem, Bezpodstawne wzbogacenie, „Studia Prawa Prywatnego” 2007, nr 2, s. 60).

${ }^{38}$ Wyrok SN z 19 sierpnia 1971 r., II CR 224/71, Legalis [dostęp: 28.11.2017].

${ }^{39}$ Wyrok SN z 14 grudnia 1983 r., IV CR 450/83, „Orzecznictwo Sądów Polskich i Komisji Arbitrażowych" 1984, nr 12, poz. 250.

${ }^{40} \mathrm{Na}$ co wskazuje wyraźnie art. 2042 Codice civile (D.Lgs. n. 38/2017 [corruzione tra privati] i na co wyraźnie zwracał uwagę W. Serda (Nienależne świadczenie, Warszawa 1988, s. 48).

${ }^{41}$ E. Łętowska, op. cit., s. 52.

${ }^{42}$ Dz. U. 2017, poz. 776 (dalej: u.p.w.p.). Szerzej na ten temat: P. Podrecki, E. Traple, w: R. Skubisz (red.), Prawo własności przemystowej, Warszawa 2017, s. 367 i n.

${ }_{43}$ Por. przykładowo: wyrok SA w Krakowie z 4 lutego 2015 r., I ACa 1600/14, Legalis.

${ }^{44}$ Wyrok SN: z 21 grudnia 2005 r., IV CK 305/05, Legalis; z 26 czerwca 2001 r., III CKN 379/00, Legalis; z 11 maja 2006 r., I CSK 118/05, Legalis; orzeczenie SN z 15 września 1945 r., C I 116/45, „Państwo i Prawo” 1946, z. 4, s. 120; uzasadnienie uchwały SN z 27 kwietnia 1995 r., III CZP 46/95, „Orzecznictwo Sądu Najwyższego Izby Cywilnej” 1995, nr 7-8, poz. 114.

${ }^{45}$ Wyrok SN z 14 lipca 1998 r., III CKN 578/97, „Orzecznictwo Sądu Najwyższego Izby Cywilnej" 1999, nr 3, poz. 49.

${ }^{46}$ Por. późniejsze poglądy A. Ohanowicza (Bezpodstawne..., s. 514-516).

${ }_{47}$ Tak poczat kowo: A. Ohanowicz, Zbieg norm w polskim prawie cywilnym, Warszawa 1963, s. 129; odmiennie: T. Dybowski, Ochrona wtasności (rei vindicatio, actio negatoria), Warszawa 1969, s. 236. 
Nadto zwraca się uwagę na fakt, że bezpodstawne wzbogacenie obejmuje znaczną liczbę przypadków ${ }^{48}$, dlatego może konkurować z nawet z najbardziej podstawowymi skargami prawa cywilnego, w tym z deliktu bądź odpowiedzialności kontraktowej. Podstawowa różnica między bezpodstawnym wzbogaceniem a roszczeniami z innych tytułów polega na tym, że w kondykcji nie występuje prawo podmiotowe, z którego można by dochodzić roszczenia, względnie prawo to wygasło. Dlatego też nie może konkurować z pozostałymi roszczeniami, opierającymi się na prawie podmiotowym ${ }^{49}$. Z tych właśnie względów dąży się w orzecznictwie do ujmowania bezpodstawnego wzbogacenia jako ultima ratio przysługującego wyłącznie wtedy, gdy brak jest innego środka prawnego ${ }^{50}$.

Na rzecz autonomiczności roszczenia z bezpodstawnego wzbogacenia częstokrotnie powołuje się fakt, że polski Kodeks cywilny - w przeciwieństwie do Codice civile - nie wyłącza wyraźnie konkurencyjności kondykcji z 405 k.c. Tylko i wyłącznie na podstawie takiego przepisu można by stawiać tezy o pomocniczości bezpodstawnego wzbogacenia w stosunku do innych roszczeń ${ }^{51}$. Dodatkowo ocenia się, że wszelka dopuszczona w prawie konkurencyjność roszczeń jest efektem zamierzonym przez ustawodawcę, zmierzającym do umocnienia praw wierzyciela, co sugeruje, że zbiegające się roszczenia maja co do zasady charakter równoległy, nie zaś następczy ${ }^{52}$.

Jak zatem wynika z powyższego, na tle instytucji bezpodstawnego wzbogacenia toczą się liczne spory co do nawet najbardziej istotnych kwestii, w tym możliwości samego dochodzenia roszczenia kondykcyjnego. Równie uprawnione są przy tym zarówno poglądy opowiadające się za niezależnością bezpodstawnego wzbogacenia, jak i te skłaniające się do subsydiarności kondykcji. Zamiarem autora tego artykułu nie jest zajęcie stanowiska w spornych od lat kwestiach z art. 405 i 414 k.c., lecz podkreślenie, jak znaczne rozbieżności zachodza w literaturze i doktrynie prawa cywilnego.

Rozbieżności te mają ogromne znaczenie również dla teorii i praktyki prawa pracy. Wielokrotnie w praktyce prawa pracy dochodzi do sytuacji, które moga zostać uznane za bezpodstawne wzbogacenie pracownika. Najbardziej oczywistym przykładem jest wypłacenie pracownikowi wynagrodzenia wyższego niż należne ${ }^{53}$ czy też pobranie przez niego nienależnej premii, nagrody ${ }^{54}$.

${ }^{48}$ Wyrok SN z 21 marca 2007 r., I CSK 458/2006, Lex nr 253397.

49 A. Ohanowicz, Niestuszne wzbogacenie..., s. 436.

${ }^{50}$ Z uzasadnienia uchwały SN z 27 kwietnia 1995 r., III CZP 46/95 (,Orzecznictwo Sądu Najwyższego Izby Cywilnej” 1995, nr 7-8, poz. 114): „Ogólnie, przepisy o bezpodstawnym wzbogaceniu należy stosować m.in. wtedy, gdy nie ma innego środka prawnego, przy wykorzystaniu którego możliwe byłoby przywrócenie równowagi majątkowej, naruszonej bez prawnego uzasadnienia”.

${ }^{51}$ W. Serda, Nienależne świadczenie, s. 48; W. Dubis, Zbieg roszczeń a skarga z bezpodstawnego wzbogacenia, „Przegląd Sądowy” 2002, nr 1, s. 36.

${ }_{52}$ W. Dubis, w: E. Gniewek, K. Pietrzykowski (red.), Kodeks cywilny. Komentarz, wyd. 8, Warszawa 2017, s. 812-813.

${ }^{53}$ Orzeczenie SN z 29 stycznia 1975 r., III PRN 67/74, „Orzecznictwo Sądu Najwyższego Izby Cywilnej, Pracy i Ubezpieczeń Społecznych” 1975, nr 7-8, poz. 123.

${ }^{54}$ Lecz tylko i wyłącznie, gdy premię tę otrzymuje. Jeśli jednak jest jednocześnie osoba, która premię te przekazuje, jako osoba zarządzająca zakładem pracy w imieniu pracodawcy (art. $3^{1}$ 
W wielu przypadkach orzecznictwo SN przyjmuje ograniczenie ${ }^{55}$ lub też w ogóle wyłączenie obowiązku zwrotu po stronie pracownika ${ }^{56}$. Warto przywołać również wyrok SN z 12 kwietnia 2012 r. (II PK 174/11) ) $^{57}$, że pracownik, który otrzymał nienależne świadczenie, musi się liczyć z zastosowaniem przepisów o bezpodstawnym wzbogaceniu. Równocześnie jednak przyjmuje się, że z odpowiedzialnością na podstawie przepisów prawa pracy jest odpowiedzialność z bezpodstawnego wzbogacenia, jako że reżim odpowiedzialności pracowniczej jest z reguły „korzystniejszy”.

W ocenie autora tego artykułu stanowiska sądów pracy (w tym SN) w sprawach na tle bezpodstawnego wzbogacenia pracowników czy pracodawców w znacznej mierze pomija kluczowe dla kondykcji zagadnienia, niekiedy tylko je sygnalizuje. W sporach tych, co zrozumiałe, sądy dokonują oceny przez pryzmat bardziej prawa pracy niż prawa cywilnego, sięgając do niego przez art. 300 k.p. Wówczas sądy pracy nakładają kolejne kryterium, mianowicie zgodność z zasadami prawa pracy, w kwestii zarówno powstania samego roszczenia, jak i w odniesieniu do możliwości jego dochodzenia ${ }^{58}$. Wyjaśnia się, że przepisy o kondykcji, jako „zbyt rozciagliwe”, muszą znaleźć zastosowanie odpowiednio, w szczególności ich stosowanie nie może prowadzić do podważenia sensu ochronnych regulacji odpowiedzialności pracowniczej, w tym ograniczenia odpowiedzialności do trzymiesięcznego wynagrodzenia ${ }^{59}$. Stanowisko to, szeroko popierane, prowadzi niekiedy do daleko idących skutków. Przyjmuje się, przykładowo, że pracownik nie musi liczyć się z obowiązkiem zwrotu wynagrodzenia, przekazanego przez pracodawcę posługującego się w tym celu wyspecjalizowanymi służbami ${ }^{60}$.

Warto zauważyć, że tego rodzaju zapatrywanie niesie z sobą spore ryzyko. Może dojść do sytuacji, gdy pracownik, otrzymawszy omyłkowo przysporzenie wielokrotnie przewyższające jego wynagrodzenie, nie będzie w ogóle zobowiązany do zwrotu lub tylko do zwrotu niewielkiej jego części. W ocenie autora niniejszego opracowania jest to stanowisko niezgodne z prawem i stoi w sprzeczności z naturą instytucji bezpodstawnego wzbogacenia.

Problem ten wynika, zdaniem autora, ze zbyt waskiego rozumienia omawianej instytucji przy jednoczesnym - nieuzasadnionym - ograniczaniu roszczenia

k.p.), to - wedle SN - odpowiada na podstawie art. 114 i n. k.p. (por. wyrok SN z 19 października 2007 r., II PK 74/07, „Orzecznictwo Sądu Najwyższego. Izba Administracyjna, Pracy i Ubezpieczeń Społecznych” 2008, nr 23-24, poz. 349, s. 1003).

${ }_{55}$ Wyrok SN z 27 maja 1999 r., I PKN 78/99, „Orzecznictwo Sądu Najwyższego. Izba Administracyjna, Pracy i Ubezpieczeń Społecznych” 2000, nr 18, poz. 682.

${ }^{56}$ Wyrok SN z 8 czerwca 2010 r., I PK 31/10, „Monitor Prawniczy” 2010, nr 9, s. 450.

57 „Monitor Prawniczy” 2012, nr 8, s. 425.

${ }^{58}$ Przypomnieć należy, że zgodnie z art. 409 k.c.: „Obowiązek wydania korzyści lub zwrotu jej wartości wygasa, jeżeli ten, kto korzyść uzyskał, zużył ją lub utracił w taki sposób, że nie jest już wzbogacony, chyba że wyzbywając się korzyści lub zużywając ją powinien był liczyć się z obowiązkiem zwrotu". Judykatura sądów pracy w sposób specyficzny ocenia właśnie powinność liczenia się z obowiązkiem zwrotu w prawie pracy.

${ }^{59}$ Por. uzasadnienie wyroku SN z 27 maja 1999 r., I PKN 78/99, „Orzecznictwo Sądu Najwyższego. Izba Administracyjna, Pracy i Ubezpieczeń Społecznych” 2000, nr 18, poz. 682.

${ }^{60}$ Por. wyrok SN z 7 sierpnia 2001 r., I PKN 408/00, „Orzecznictwo Sądu Najwyższego. Izba Administracyjna, Pracy i Ubezpieczeń Społecznych” 2003, nr 13, poz. 305. 
kondykcyjnego, stosownie do art. 300 k.p. Autor artykułu zajmuje stanowisko, że w sprawach bezpodstawnego wzbogacenia pracowników sięganie do art. 300 k.p. jest zbędne, przepisy art. 405-414 k.c. zaś winny mieć zastosowanie wprost.

Stanowisko to poparte jest następującymi założeniami. Zauważyć trzeba, że bezpodstawne wzbogacenie, jak to wykazano wyżej, nie opiera się na żadnym stosunku prawnym, jego podstawowa przesłanka jest właśnie brak podstawy prawnej przysporzenia. To właśnie nieistnienie podstawy prawnej przysporzenia, rozumianej jako przyczyna, która usprawiedliwia wzbogacenie, czyni je zgodne $\mathrm{z}$ porządkiem prawnym ${ }^{61}-$ klaruje się różnica między odpowiedzialnością kondykcyjną a pozostałymi reżimami odpowiedzialności na gruncie prawa prywatnego. Niemożliwe jest zatem poszukiwanie oparcia dla bezpodstawnego wzbogacenia w stosunku pracy. Istnieje bowiem szereg przypadków, kiedy przysporzenie poczynione na rzecz pracownika nie będzie miało oparcia ani w Kodeksie pracy czy ustawach szczegółowych prawa pracy, ani w regulacjach zakładowych ${ }^{62}$, co jednoznacznie osadza przyszłe roszczenie pracodawcy o zwrot w reżimie odpowiedzialności kondykcyjnej. Okoliczność ta jednocześnie eliminuje dopuszczalność sięgania przez art. 300 k.p., który zezwala na pomocnicze sięganie do przepisów Kodeksu cywilnego wyłącznie „do stosunku pracy”, nie zaś do kwestii nieobjętych tych stosunkiem. Regulacje kodeksowe w tym zakresie winny być wyłączne. Nie każde wzbogacenie czy przysporzenie uzyskane „przy okazj”” świadczenia pracy jest świadczeniem w ramach stosunku pracy - co widoczne jest najwyraźniej właśnie przy bezpodstawnym wzbogaceniu. Ugruntowane i pewne w orzecznictwie jest bowiem to, że brak podstawy prawnej w rozumieniu art. 405 k.c. występuje także wtedy, gdy strony wprawdzie związane są umowa, jednakże przysporzenie nie znajdowało usprawiedliwienia w jej postanowieniach ${ }^{63}$. Tym samym nie można konstruować założeń o ograniczeniu odpowiedzialności z tytułu kondykcji wynikających z przepisów k.p. Z podobnych względów orzecznictwo sądów pracy nie rozciaga przepisów o odpowiedzialności pracowniczej na umowy o zakazie konkurencji po ustaniu stosunku pracy ${ }^{64}$. W jednym i drugim przypadku sprawa nie ma bowiem charakteru pracowniczego, znajduje się poza stosunkiem pracy, z tą tylko różnica, że bezpodstawne wzbogacenie pracownika może wystapić, w przeciwieństwie do niepracowniczego zakazu konkurencji, równolegle z trwaniem stosunku pracy.

Zapatrywanie to może spotkać się z zarzutem postulowania sprzecznego z prawem obniżenia standardów ochrony pracowniczej. Pracownik bezpodstawnie wzbogacony byłby bowiem narażony na zwrot wzbogacenia w pełnej wysokości (nie zaś, jak to przewiduje art. 119 k.p., w wysokości trzymiesięcznego wynagrodzenia) w terminie nawet dziesięciu lat (nie zaś trzech lat - sto-

61 A. Ohanowicz, Bezpodstawne..., s. 486.

62 Najbardziej oczywistym przykładem jest wypłacenie pracownikowi dodatkowego wynagrodzenia czy też omyłkowe przyznanie premii, której, w danych okolicznościach, nie przewidywał układ zbiorowy czy regulamin wynagradzania.

63 Por. wyrok SN z 27 lutego 2004 r., V CK 293/03, „Orzecznictwo Sądu Najwyższego. Izby Cywilnej" 2005, nr 3, poz. 51.

64 Por. wyrok SN z 16 listopada 2004 r., I PK 59/04, Legalis. 
sownie do art. $291 \S 1$ k.p.). Zarzut ten byłby jednak całkowicie nieuzasadniony. W pierwszej kolejności nieracjonalne byłoby rozważanie sprzeczności z zasadami prawa pracy sytuacji, która pozostaje - jak już wykazano - poza stosunkiem pracy. Należy zaznaczyć też, że w orzecznictwie wyraźnie podkreśla się, że prawną przesłanką wzbogacenia jest przede wszystkim stosunek zobowiązaniowy. Wykluczone jest powoływanie się na art. 405 i n. k.c. w sytuacji, gdy dana osoba nie spełnia swojego świadczenia, mieszczącego się w granicach istniejącego stosunku zobowiązaniowego ${ }^{65}$. Pogląd ten należy w pełni zaaprobować także w sprawach bezpodstawnego wzbogacenia na tle stosunków pracowniczych. Gdyby przyjąć, że w każdym przypadku nadmierne świadczenie na rzecz pracownika byłoby jednocześnie jego bezpodstawnym wzbogaceniem, można byłoby praktycznie ominać wszystkie przepisy Kodeksu pracy o odpowiedzialności pracowniczej. Wtedy roszczenie kondykcyjne konkurowałoby, i w zasadzie wykluczałoby, odpowiedzialność kontraktowa pracownika, co w istocie spowodowaoby, że ochronne przepisy prawa pracy zostałyby w ogóle wyłączone w większości wypadków.

W pierwszej kolejności należałoby raczej sprawdzić, czy dany stan faktyczny mieści się w ramach stosunku pracy, czemu służyć powinny, oczywiście, przepisy prawa pracy, w tym powszechnie obowiąujace i zakładowe. Powracajacc do przykładu pracownika otrzymujacego dwukrotne wynagrodzenie w danym miesiacu, trzeba by dokonać oceny, czy np. układ zbiorowy czy regulamin pracy nie zezwala na przyznanie pracownikowi znaczacej premii. Jeśli odpowiedź byłaby negatywna, to bez wątpliwości można byłoby przejść na reżim odpowiedzialności z art. 405 i n. k.c. Gdyby natomiast układ zbiorowy zezwalał na premię wyczerpująca jedynie część przysporzenia, można byłoby rozważyć, że pracownik bezpodstawnie wzbogacony winien się liczyć z obowiązkiem zwrotu z art. 409 k.c.

Co do zasady godne aprobaty jest przy tym stanowisko wyrażone w orzecznictwie Sądu Najwyższego ${ }^{66}$, że przy ocenie, czy pracownik winien liczyć się z obowiązkiem zwrotu kwot niezasadnie mu przyznanych, sąd winien wziąć pod rozwagę zasadę uprzywilejowania pracownika, a w tym także możliwość przyznania pracownikowi wyższych należności, aniżeli wynikających z obowiązujących przepisów płacowych. Taka wykładnia prawnego pojęcia „powinności zwrotu” stanowiłaby należytą ochronę słabszej strony stosunku pracy w sytuacjach, kiedy nie należałoby oczekiwać od pracownika, że przyznana mu np. nagrodę zakładową wyda, będąc całkowicie przekonany, że została mu przekazana celowo przez pracodawcę ${ }^{67}$. Z drugiej jednak strony nie można pomijać sytuacji, gdy przekazane pracownikowi świadczenie będzie w ewidentny sposób nienależne, np. w razie przyznania pracownikowi premii za skuteczna i wydajna pracę w chwili, gdy przebywa on na urlopie bezpłatnym. W takich okolicznościach pracownik winien z góry liczyć się z powinnością zwrotu.

${ }^{65}$ Por. wyrok SN z 7 maja 2009 r., IV CSK 523/08, „Monitor Prawniczy” 2010, nr 20, s. 1138 i powołane w uzasadnieniu orzecznictwo.

66 Wyrok SN z 20 czerwca 2001 r., I PKN 511/00, „Orzecznictwo Sądów Polskich” 2003, nr 10, poz. 131 z glosą krytyczną A. Drozda, „Orzecznictwo Sądów Polskich” 2003, nr 10, s. 542.

${ }_{67}$ Przy niniejszych rozważaniach celowo pominięto art. 411 pkt 1 k.c. 
Niezależnie od powyższego, w sprawach bezpodstawnego wzbogacenia pracowniczego możliwe byłoby także zastosowanie art. 8 k.p. lub też, co wydaje się bardziej zasadne, art. 5 k.c. w sytuacji, gdyby zadośćuczynienie roszczeniu pracodawcy godziło wyraźnie oraz dobitnie w zasady współżycia społecznego. Idąc dalej, nawet gdyby przyjąć, że roszczenie z kodnykcji ma charakter subsydiarny do roszczenia głównego - co, jak podkreślano, nie jest bezdyskusyjne - w tym przypadku do roszczeń ze stosunku pracy, w wyniku wyżej opisanego zabiegu doszłoby do jednoznacznego wyeliminowania konkurującego reżimu. Jedyną prawną możliwością przywrócenia stanu równowagi sprzed nieuzasadnionego przesunięcia majątków stałoby się bezpodstawne wzbogacenie.

Konkludując, autor niniejszego opracowania wyraża pogląd, że w sprawach pracowniczych na tle instytucji bezpodstawnego wzbogacenia nieuzasadnione jest sięganie przez art. 300 k.p. do regulacji art. $405 \mathrm{i}$ n. k.c., te bowiem znajduja zastosowanie wprost. Dotychczasowa praktyka polegajaca na ocenie instytucji bezpodstawnego wzbogacenia przez pryzmat prawa pracy jest, w ocenie autora, błędna, nie uwzględnia specyfiki omawianej instytucji, w tym jej najistotniejszej przesłanki - braku podstawy prawnej wzbogacenia. Ze względu na tę właśnie okoliczność roszczenie kondykcyjne nie jest roszczeniem konkurujacym ze stosunkiem pracy w myśl art. 414 k.c., bardziej lub mniej korzystnym dla wzbogaconego pracownika. Bezpodstawne wzbogacenie jest wtedy roszczeniem jedynym.

mgr Arkadiusz Gawron

Uniwersytet Ślaski

arek.nalepka@gmail.com

\section{UNJUST ENRICHMENT OF AN EMPLOYEE}

Summary

In the article the author's opinion on the employee's liability regulated by the Labour Code provisions regarding unjust enrichment regulated in Articles 405-414 of the Civil Code is presented. First both forms of liability are identified and the earlier views of the case law and scholars on the employee's liability for unjust enrichment are analysed. The author ultimately aims at entering into polemics with the current views of the representatives of science and the judiciary, to end with the thesis pointing to the need for the regulation of the Civil Code in matters relating to employee's unjust enrichment. 
